\title{
DEÁK JÓZSEF
}

\section{Etnikai-e vagy multikulturális a bünözés?}

Magyarországon 2008 és 2009 között kilenc helyszínen történtek rasszista indíttatású támadások, amelyeknek hat halálos áldozatuk volt. ${ }^{1}$

A szervezett banda országszerte kilenc helyszínen lőfegyverekkel, gyújtópalackokkal roma családok otthonait támadta meg. A büncselekmény-sorozatban hat ember, köztük egy gyerek meghalt, öten súlyosan megsebesültek. Az elkövetők 78 lövést adtak le, 11 Molotov-koktélt dobtak a megtámadott épületekre, és 55 ember testi épségét veszélyeztették. ${ }^{2}$

A csaknem tíz évvel ezelött bekövetkezett tragikus kimenetelü büncselekmény-sorozat akkoriban ismét ráirányította az ország közvéleményének figyelmét a magyarországi romákkal történő együttélésre, az interkulturális nevelés jelentőségére. Miután pedig az interkulturális nevelés problematikáját napjainkban az Európát elárasztó migrációs hullám ismét a figyelem középpontjába helyezte, érdemes megvizsgálni, miként vett részt a kezdetektöl - például a „cigánybünözés” fogalom létjogosultságát vs. alaptalanságát taglaló írásaival - a Belügyi Szemle a belügyi állomány, föként a rendőrség interkulturális nevelésében, s hogy mennyire időtállók a főbb megállapítások.

\section{Interkulturalitás - multikulturalitás}

Európai uniós tagállamként az interkulturalitás és a multikulturalitás fogalma megkülönböztetett figyelmet élvez hazánk oktatáspolitikai dokumentumaiban is. Az UNESCO által javasolt definíció szerint az ,,interkulturális terminust a kultúrák közötti interakció értelmében használjuk, a multikulturális fogalom pedig kölcsönös együttélést, és megértést jelent egyazon társadalomban élö különbözö kultúrák között”’3.

\footnotetext{
1 Fővárosi Törvényszék, 22.P.24.264/2013/7.

2 Romagyilkosságok - A Fővárosi Ítélőtáblára továbbították az ügyet. Haon.hu, 2014. november 28 http://www.haon.hu/romagyilkossagok-a-fovarosi-itelotablara-tovabbitottak-az-ugyet/2708736

3 Lakatosné Török Erika - Dorner Helga: Pedagógusok interkulturális kompetenciája nemzetközi partnerségben. Új Pedagógiai Szemle, 2007. október. http://epa.oszk.hu/00000/00035/00117/2007-10-taTobbek-Pedagogusok.html
} 
A két fogalom sem nem különböző, sem nem azonos. Egyszerre van jelen a szakirodalomban. Az Európai Tanács szóhasználatában a multikulturalizmus egyfajta szemléletmód, míg a kulturális sokféleség és a multikulturalitás arra a tapasztalati tényre utal, hogy egy adott területen és adott társadalmi szervezeten belül különféle kultúrák léteznek és hathatnak egymásra. Az interkulturalitás fogalma helyett a kultúrák közötti párbeszéd definícióját adják meg (angolul intercultural dialogue), kultúrák közötti párbeszéd, amikor is különböző etnikai, kulturális, vallási és nyelvi háttérrel, illetve örökséggel jellemezhető egyének vagy csoportok közötti nyitott és a másik fél véleményének tiszteletben tartása mellett megvalósuló eszmecsere, amelynek alapja a kölcsönös megértés és tisztelet. Ez minden szintre vonatkozik: a társadalmon belül, az európai társadalmak között, valamint Európa és a világ más részei közötti párbeszédre egyaránt. Tehát Európában az interkulturalizmus fogalmán általában társadalmi csoportok közötti interakciót értenek, míg a multikulturalizmus fogalmán a társadalom struktúráját. ${ }^{4}$

A Belügyminisztérium irányítása alatt müködő rendészeti szervek közül a rendőrség és a büntetés-végrehajtás, továbbá a Bevándorlási és Menekültügyi Hivatal mindennapi munkája, a polgárokkal, ügyfelekkel történő közvetlen érintkezés is gyakran feltételezi, sőt egyre inkább megköveteli az interkulturális ismereteket, toleranciát, empátiát.

\section{Mühelyvita a „cigánybünözésről”"}

A cigányok Északnyugat-Indiából elhagyva őshazájukat, Indiát, szóródtak szét a nagyvilágban. Tömeges megjelenésük Európában - a Duna mentén is a XIV. századra tehető. A cigány kultúra eltér az európaitól, a hagyományos cigány ízlésvilág, viselkedés, gondolkodásmód, erkölcsi rendszer más, mint az európai. ${ }^{5}$

A cigány lakosság társadalmi beilleszkedésével kapcsolatban 1961. június 20-án jelent meg az MSZMP Politikai Bizottságának első párthatározata ${ }^{6}$,

\footnotetext{
4 Páva Rita: Interkulturális, multikulturális oktatás alapjai. ELTE, Budapest, 2015 http://pedagoguskepzes.elte.hu/images/anyagok/ii3/27_interkulturalis_mutikulturalis_oktatas_alapjai.pdf

5 Rostás-Farkas György: A cigányság hagyomány- és hiedelemvilága. Cigány Tudományos és Müvészeti Társaság, Budapest, 2000, 12-23. o.

6 Az MSZMP Központi Bizottsága Politikai Bizottságának határozata a cigánylakosság helyzetének megjavításával kapcsolatos egyes feladatokról (1961. június 20.). A Magyar Szocialista Munkáspárt Határozatai és Dokumentumai 1956-1962. Kossuth Könyvkiadó, Budapest, 1973, 519-521. o.
} 
amely megszabta e téren az állami és társadalmi szervek legfontosabb feladatait. 1960. január 1-jén, Magyarországon 186536 cigány ember élt, az ország összlakosságának 1,8 százaléka. $^{?}$

A kérdés már csak az érintettek nagy száma és súlyos elmaradottsága miatt is fontos társadalmi ügy. Ugyanis, mint akkoriban már nyilvánvalóvá vált, a cigányok problémáinak megoldása nemcsak anyagi, kulturális és egészségügyi kérdés, hanem - a társadalmi réteg rendkívül elmaradott életkörülményei okán - politikaivá is vált. A probléma társadalmi, belügyi jelentőségét, súlyát kiemeli, hogy már az 1963-ban megalakuló Belügyi Szemle ${ }^{8}$ első számának első harmadában helyet kap egy vitaindító cikk. A párthatározatból a belügyi szervekre háruló feladatokkal részleteiben foglalkozott a színre lépő lap megjelenése évének első felében folytatott vita. ${ }^{9}$

A hozzászólók többsége hangsúlyozta, hogy a „cigánybünözés” felszámolásának fontos előfeltétele a cigány lakosság teljes társadalmi beilleszkedése. Sok értékes javaslat is elhangzott, amelyek azóta a rendőri szervek munkájában érvényesültek, és hozzájárultak a „cigánybünözés” elleni harc eredményeihez. ${ }^{10}$

A témában - az akkoriban elképzelhetö - nemzetközi kitekintést szolgálta a hazaival sok rokon vonást mutató szovjet helyzetet, annak társadalmi, rendőrségi kezelését ismertető anyag. Például arról, hogy az egymillió-kétszázezres cigány lakosság körében , Több helyen, ahol a cigányok letelepedtek, a milícia szerveinek kezdeményezésére társadalmi bíróságok jöttek létre cigány és nem cigány lakosokból. Amelyek kisebb jelentöségü jogellenes vagy egyéb, az együttélés szabályaival nem összeegyeztethetö cselekményekért vonják felelösségre az ezeket elkövetö cigányokat, és ilyen módon közösségi, társadalmi ráhatások segitségével nevelnek. [...] A cigányság-tehetséges népcsoport, amely muzikális lélekkel, a zene iránti természetes érzékkel, $s$ találékony ésszel rendelkezik. Minden lehetségest meg kell tenni társadalmi és emberi felemelkedésük érdekében." ${ }_{l l}$

\footnotetext{
7 Dobos János: A cigánylakosság társadalmi asszimilációja és a cigánybünözés. Belügyi Szemle, 1966/6., 31. o.

8 József Deák: The Police, then Interior Review for the Forming of the Science of Law Enforcement; from its Beginning, to the Change of the Political System. West Bohemian Historical Review, no. 2, 2014, p. 241.

9 Nemes Alajos: A cigánylakosság helyzetének megjavításáról szóló párthatározat végrehajtásának tapasztalatai Baranya megyében. Belügyi Szemle, 1963/1., 30. o.

10 Dobos János: i. m.

11 Schiffer János - Dobos János: A cigánylakossággal kapcsolatos problémák a Szovjetunióban. Belügyi Szemle, 1963/3., 66-73. o.
} 
Nemes Alajos írásából az is kiderül, hogy a Belügyminisztérium vezetői már jóval az említett politikai bizottsági határozat megszületése előtt úgy értékelték, hogy a cigány lakosság elmaradottságának felszámolása nem rendöri feladat, hanem elsősorban társadalmi kérdés, amelyet csak a társadalom összefogásával, a különböző, érintett szervek összehangolt intézkedésével lehet megoldani, ebben természetesen fontos szerepe van a rendőrségnek is, elsősorban a bünöző cigányok kapcsán. E megállapítás nyomán a cigányok által elkövetett büncselekmények száma jelentösen, 1961-ben harminc százalékkal csökkent (1954-hez viszonyítva). Ez után a szerző részletes statisztikai adatokkal alátámasztva taglalja a Baranya megyében élő cigány lakosság jelenlegi helyzetét, külön kitérve a munkakörülményekre, a kulturális, egészségügyi viszonyokra, a társadalmi beilleszkedésük helyzetére. A lakosság három és fél százalékát kitevő cigányok követik el az összbüncselekmények hét százalékát. A megyében nyilvántartott szokásos büntettesek huszonhat százaléka cigány. A cigányok helyzetének megváltoztatására megtett, illetve tervezett intézkedések számbavételekor a szerző külön kitér a társadalmi vonalon szükséges teendőkre, az állami és gazdasági szerveknél elengedhetetlenekre, valamint a rendőri feladatokra. ${ }^{12}$

Ezeket a rendőri feladatokat az 1963 júniusában megjelenő első vitazáró cikkben Györök Ferenc tömören így foglalja össze: „, A cigánybünözöknek állandóan érezniük kell, hogy a rendörség ellenörzi, számon tartja tevékenységüket, látniuk kell, hogy bünelkövetés esetén leleplezésük elkerülhetetlen. Ez a visszatartó hatás a társadalmi beilleszkedés útjára tereli őket." ${ }^{\prime 3}$

Valószínűleg ezek az írások is jelentősen hozzájárultak az egységes rendőrségi és ügyészségi bünügyi statisztikai rendszer „cigánybűnöző” kategóriájának létrejöttéhez.

A belügyminiszter és a legfőbb ügyész közös utasítása alapján 1964. január 1-jén hatályba lépett az egységes rendőrségi, ügyészségi bünügyi statisztika. ${ }^{14}$

Ennek kezdetektöl fogva az egyik legfőbb hiányossága, hogy a különböző bünözői kategóriák (fiatalkorúak, visszaesők, veszélyes bünözők, cigány- [a szerző kiemelése] és utazó bünözők) bünözését csupán azok szerint az arányok szerint mérte, amelyeket az elkövetők között elfoglalnak. ${ }^{15}$

\footnotetext{
12 Nemes Alajos: i. m. 29. o.

13 Györök Ferenc: A cigánylakosság társadalmi beilleszkedése. Belügyi Szemle, 1963/7., 93. o.

14 Tóth Tihamér: Viktimológiai jellegủ bủnügyi statisztikai adatgyüjtés szükségességéről. Belügyi Szemle, 1973/10., 69. o.

15 Dobos János: Az elkövetői kategóriák értékelése. Belügyi Szemle, 1988/1., 10. o.
} 
Az egységes rendőrségi, ügyészségi bűnügyi statisztikában az előbbiek szerint már korán próbálták körvonalazni - külön kategóriát létrehozva számukra - a „cigány bünözőket”.

E téma kapcsán évtizedeken át helyet kap a folyóiratban több átfogó, országos vagy megyei rendőr-főkapitányság területén a cigányság helyzetét, bűnözésének jellemzőit, a szükséges teendőket számba vevő, a megjelenő anyagokat új megállapításokkal, mind több külföldi tapasztalattal kiegészítő tanulmány.

Az első időszak anyagait Dobos János említett cikke összegzi, 1966 júniusában, leszögezve, hogy a cigány lakosság társadalmi beilleszkedésének üteme és a „cigánybünözés” helyzete között szoros összefüggés van. A befejezett ügyek 1964-1965. évi vizsgálata arra utal, hogy több mint tíz százalékal nőtt azoknak a vádemeléssel átadott ügyeknek a száma, amelyeket cigány bünözők követtek el. A „cigánybünözés” területi eloszlását vizsgálva a szerző megállapítja, hogy elég magas a „cigánybünözés” (mind a vádemeléssel átadott ügyek, mind a terheltté nyilvánítottak több mint tíz százaléka) Borsod, Nógrád, Szabolcs és Tolna megyében. Ugyanakkor a fennmaradó tizenöt megyében a „cigánybünözés” stagnál, vagy csökkenő tendenciát mutat. Emelkedés csak Csongrád, Fejér, Győr és Szabolcs megyében volt tapasztalható. ${ }^{16}$

Tudományos élet rovatában a lap, a teljességre törekedve, időről időre helyet adott a problémával kapcsolatos civil nézőpontoknak is. A cigány lakosság társadalmi asszimilációjának korabeli társadalmi megítélését jól tükrözte a területen folyó munka tapasztalatait, az egészségügyi szakbizottság jelentését, a cigány telepek felszámolását elősegítő 2014/1964. (V. 4.) kormányhatározat végrehajtásának problémáit feltáró anyag. A beilleszkedés nehézségeinek vizsgálatára, kiküszöbölésére felállított Országos Társadalmi Bizottság 1964 decemberében, az érdekelt szaktárcák és társadalmi szervezetek képviselői részvételével összehívott munkaértekezleten tekintette át a cigány lakosság helyzetét. Az ankéton egyebek közt elhangzott, hogy a telepek leggyakoribb hivatalos látogatói még mindig a rendőrök és az egészségügyi dolgozók. A rendőrség munkája kapcsán a Minisztertanács tanácsszervek osztályának munkatársa elmondta, hogy a rendőrök intézkedéseiben az előző évekhez képest mérhetően pozitív változás állt be. A cigány lakosság társadalmi beilleszkedése érdekben kötelességükön túlmenően is igen sokat tesznek. ${ }^{17}$

16 Dobos János: A cigánylakosság társadalmi asszimilációja és a cigánybünözés. Belügyi Szemle, 1966/6., 37. o.

17 Marosán Lajosné - Vácziné dr. Konkoly Magda: A cigánylakosság társadalmi asszimilációja. Belügyi Szemle, 1965/3., 47-54. o. 


\section{A „cigányútra” tévedt „cigány bünöző” fogalma}

A Belügyi Szemlében, „cigánybünözés” témában az összegzések után sem csökkent a szerkesztőségbe küldött cikkek mennyisége, tükrözve a téma aktualitását.

Néhány közülük:

- A cigánylakosság bünözésének társadalmi problémáiról. Csendes Károly, a legfőbb ügyész helyettese az 1972/6. számban megjelenő írásában megemlíti, hogy a szabadságvesztésre ítélt cigányok többsége életében először a börtönben kerül viszonylag kulturált körülmények közé (20. o.).

- A Zala megyében élö cigánylakosság helyzete és bünözésben való részvétele (Bognár Ferenc rendör alezredes, 1972/7.).

- A cigánylakosság bünözésének helyzete Békés megyében (Sajti Imre rendör alezredes és Fekete Béla rendör hadnagy, 1972/9.).

- A cigányság helyzete és bünözése Szabolcs-Szatmár megyében (Kerezsi Tamás rendőr föhadnagy, 1972/10.)

- A cigánybünözés felszámolását akadályozó tényezők (Madách Olivér rendör alezredes és Fehér Lajos rendőr alezredes hozzászólása a legfőbb ügyész cikkéhez, 1972/11.)

- A cigánylakosság társadalmi beilleszkedése és bünözése Tolna megyében (Farkas Miklós rendör örnagy, 1973/7.)

- Fiatalkorú cigányok által elkövetett emberölés nyomozása (Süle József rendör alezredes, 1973/9.)

A vita összefoglalása helyett a szerkesztőség ezúttal beszélgetésre hívta a cigányság problémáinak jó ismeröit: Zagyva Imrét, a Minisztertanács Tanácsi Hivatala fóosztályvezető-helyettesét, Ágoston Zoltánt, a Pest Megyei Tanács VB igazgatási osztályvezetőjét és Dobos János rendőr őrnagyot, a BM bünügyi osztály vagyonvédelmi alosztályának vezetőjét. A Konzultáció rovatban közölt anyag célja, hogy az elhangzott vélemények árnyalják a cigányság gondjairól eddig alkotott képet, és orientálják az olvasókat mindennapi munkájuk végzésében. ${ }^{18}$

1976 júniusában, a „cigánybűnözés” helyzetének megoldatlansága hívta életre e témában a Borsi Zoltán és Halász Kálmán Bünözés és cigánybünö$z e ́ s^{19}$ vitaindító tanulmányával a következő cikkfolyamot.

18 Nyerges Lajos (szerk.): A cigányság társadalmi beilleszkedéséről és bűnözéséről. Belügyi Szemle, 1973/11., 39-46. o.

19 Borsi Zoltán - Halász Kálmán: Bünözés és cigánybűnözés. Belügyi Szemle, 1976/6., 20. o. 
Hiszen minél több demográfiai, szociológiai, kriminológiai és egyéb ismérvét tárjuk fel a bünözésnek, annál pontosabb terveket dogozhatunk ki a felderítés és a bünmegelözés érdekében. ${ }^{20}$

Ebben a szellemben Tonhauser László rendör föhadnagy már $A$ budapes$t i$, szervezett” cigánybünözés elleni harc taktikájának egyes kérdéseit $\mathrm{t}^{21}$ taglalja a lap hasábjain.

A Bünözés és cigánybünözés vitaindító cikkből kiderül: „,Cigánynak kell tekinteni azokat a bünelkövetöket, akiket nem cigány környezetük is cigánynak tekint, és

- rendszeresen vagy idényjelleggel vándorolnak, tartósan nem telepszenek le és a munkát kerülik;

- a nem cigány lakosságtól elkülönülve cigánysoron, telepeken, putrikban élnek, többnyire csak alkalmi munkát végeznek,

- életmódjukban a cigány hagyományokat (vérbosszú, leányszöktetés vagy vásárlás) követik;

- bünelkövetési módszereik jellegzetesek. Például nem büntethetö korban levö gyermekeikkel vitetik véghez a büncselekményeiket, miközben azt felnött korúak biztositják stb. "’22

Ekkoriban már nagyjából háromszázezerre tehető a hazai cigány népesség száma. A kriminálstatisztikának a bünelkövetőkre vonatkozó adataiból kiderül, hogy míg a tízezer lakosra jutó kriminalitási arány a cigány bünelkövetőknél 133,4, addig a nem cigányoknál csupán 71,8 százalék. A cigány bünelkövetők korabeli aránya Bács-Kiskun, Borsod-Abaúj-Zemplén és Veszprém megyében a legmagasabb, a fővárosban és Vas megyében a legalacsonyabb. Egyes büncselekményeknél részesedési arányuk magasabb, mint a nem cigány bünelkövetőké. Különösen az erőszakos és garázda büncselekményeknél szembeötlö, hogy a cigány bünelkövetőknél ez az arány mintegy negyven százalék, míg a nem cigány bünelkövetőknél mindössze 18 százalék. A vagyon elleni büncselekmények esetében már csak másfélszer annyi, 57,3 százalék a cigány elkövető, de a fiatalkorú bünelkövetők részesedésében ismét az összes bünelkövető arányának több mint a duplája, 21,6 százalék a cigány. A gyermekkorúaknál még rosszabb a helyzet, hiszen az arányuk az összes bünelkövető közt 3,2, a cigány bünelkövetők között pedig 12 százalék. Az elemzés vé-

20 Lázár Bertalan: Az egységes új rendőrségi és ügyészségi statisztika. Belügyi Szemle, 1964/1., 16. o.

21 Tonhauser László: A budapesti „,szervezett” cigánybűnözés elleni harc taktikájának egyes kérdései. Belügyi Szemle, 1978/11., 73. o.

22 Borsi Zoltán - Halász Kálmán: i. m. 23. o. 
gi következtetés szerint a cigányság társadalmilag hátrányos helyzetén gazdasági, kulturális, szociális téren éppen úgy, mint a munkaerkölcs területén - társadalmi összefogással előnyösen változtatva az egyes és jelentős veszélyességü büncselekményeknél is minden bizonnyal csökkenthető a bünelkövetök köre. ${ }^{23}$

A következő meghatározással összevethetjük, a következő évtizedben mennyire finomodott a kategória meghatározása, de egyre inkább fény derült a „cigánybünöző” statisztikai meghatározásának problémáira is.

„Az elkövetöt cigánynak kell tekinteni, ha:

1. Cigány közösségben élnek, bejelentett lakásuk formális, rendszeresen vagy idényjelleggel vándorolnak, letelepednek ugyan, de munkát nem vállalnak,

2. életmódjukban a cigányhagyományokat követik

3. bünelkövetési módszereik hagyományosan cigány módszerek

4. olyan, a környezet által cigánynak tartott személyek, akik felhagytak a lakosságtól elkülönülö, ösi cigányéletformával, de létfenntartásukat alapvetöen cigány módszerekkel elkövetett büncselekményekböl biztositják. " ${ }^{24}$

A kétszer is előforduló, körülíratlan „cigány módszer” aligha körvonalazhatta pontosabban a „cigány” fogalmát...

Ugyanakkor a statisztikai szabályzat szerint „,nem szabad cigánynak tekinteni azokat, akik korábbi életmódjukat és szemléletüket megváltoztatva letelepednek, rendszeres munkával tartják el magukat és családjukat, szakitottak a cigány hagyományokkal és életvitelüket a becsületes dolgozó állampolgárok közé való tartós beilleszkedés jellemzi" ${ }^{25}$.

$\mathrm{Az}$ iménti részletes, de viszonylag bonyolult fogalommeghatározás értékelési problémákat vetett fel a gyakorlati alkalmazásnál, s ez ahhoz vezetett, hogy a statisztikai adatlapok kitöltésénél gyakran figyelmen kívül hagyták a cigánybünözésre vonatkozó kódjeleket. A kitöltési tájékoztatóban meghatározott feladatok egységes értelmezése érdekben adták ki a 3/1982. bünügyi első helyettesi intézkedést, a „cigány elkövetők” kódnál felmerülő hiányosságok megszüntetésére, tekintettel arra, hogy a fővárosi cigány lakosságra nem minden esetben jellemző egyebek közt a vidéken élők meghatározása. Az intézkedés azonban nem hozta meg a várt eredményt. A cigány elkövetők jelentős részét továbbra sem cigányként kódolták. Ebben továbbra is szerepe

23 Uo. 24-26. o.

24 A BRFK bűnügyi I. helyettesének 3/87. sz. Körlevele. A cigánybünözés megelőzés, felderítésének tapasztalatiról, valamint a további feladatokról szóló jelentés (161-354/1986) megküldéséröl 1987. 02. 22. Budapest Főváros Levéltára, VI.36a. 3. d.

25 A BRFK bünügyi I. helyettesének 3/82. Intézkedése A cigány bünözők helyes statisztikai számbavételéröl. Fővárosi Levéltár, VI.14.b. 4. d. 
lehetett a bonyolult fogalommeghatározásnak, de az anyag ténylegesen jelentősebbnek tartja az adatlapokat kitöltők felületességét és a parancsnoki revízió hiányát. „A cigányelkövetőkre vonatkozó kódolási hiányosságok miatt számszerüségében a valóságnak megfelelö statisztikai adatokkal nem rendelkezünk a cigánybünözésröl." ${ }^{26}$

Ezt a megállapítást támasztja alá a budapesti rendőrfőkapitány beszámolója a fơkapitányság 1988. évi tevékenységéről, az 1989. évi feladatairól: „Jelentösen emelkedett, 546-ról 2074-re, 279,95\%-kal - a cigány elkövetök száma. Ez a növekedés alapvetöen nem a bünözésben való részvételük emelkedö tendenciájával, hanem a megváltozott statisztikai adatszolgáltatási magatartással hozható összefüggésbe. A gyerekkorú elkövetök száma, viszont 473-ról 436-ra módosult." "27

Szintén 1988-ban készült a XIX. kerületi kapitányság komplex ellenőrzéséröl az a jelentés, amelynek megállapítása szerint: „, A cigány bünelkövetök száma erös szóródást mutat, amely feltehetöen a statisztikai számbavétel hiányosságainak következménye. "28

A cigányság helyzetével, bünözésével kapcsolatban, a Belügyi Szemlében összegyült anyagok (ezúttal kitekintéssel egyebek közt a szlovákiai helyzetre is; 1978/4. és 11. szám. Az utóbbiban olvashatjuk, hogy a Szlovákia lakosságának 3,9 százalékát kitevő cigányok a büncselekményekért elítéltek 12,5 százalékát képviselik; 128. o.), adatok értékelésére, 1979 májusában a folyóirat Tudományos élet rovatában Tauber István vállalkozik, A cigányok által elkövetett büncselekmények kriminológiai kutatása címü cikkében. Ekkor a cigány lakosság száma már 360 ezerre tehető, és a cigány bünelkövetés gyakorisága másfél, míg a nem cigányelkövetőké 0,73 százalék az ország összlakosságához mérten, a cigányság körében tapasztalható jelentős társadalmi, kulturális fejlődés ellenére. Ha viszont a cigányság jelenlegi létszámából indulunk ki - vagyis a regisztrált 293490 fön kívül még 67 ezer cigány lakost veszünk alapul (ezek bünözési gyakorisága az általánosnak felel meg, mármint 0,73 százaléknak) -, akkor az átlag, vagyis a cigány elkövetőknek a cigány lakossághoz viszonyított aránya 1,3 százalék. ${ }^{29}$ „,Tauber István (1949-2003) A Magyar Kriminológiai társaság, alapitó tagja, 1973-tól a Rendörtiszti Fö-

\footnotetext{
26 A BRFK bünügyi I. helyettesének 3/87.sz. Körlevele.... i. m.

27 Budapest Főváros Levéltára, VI.12.4. 34. d.

28 Budapest Főváros Levéltára, VI. 12.a.4. 32.d

29 Tauber István: A cigányok által elkövetett büncselekmények kriminológiai kutatása. Belügyi Szemle, 1979/5., 49-58. o.
} 
iskola kriminológiai tanszék tanára, 1985-töl vezetője, több mint 10 évig vizsgálta a cigányság bünözésének helyzetét." ${ }_{30}$

1988-ban, negyedszázaddal a hazai cigányság kérdéskörét felvető a Nemes Alajos-cikk után Dobos János modellként a „cigánybünözést” ${ }^{\prime 1}$ választva, bemutatja az objektívnek hitt értékelés ellentmondásait, hangsúlyozva a statisztikai adatszolgáltatás értékelésének hiányosságait. Például:

- A cigány elkövetőket az összes elkövetőtől megkülönböztető kódjelek a bünügyi statisztikában, eleinte nem szerepeltek; Csak különféle megyei fö mutatók voltak a cigánybünözési vonalvezetők felmérései alapján. A hivatalos statisztikába 1974-ben került be. ${ }^{32}$

- A kitöltési utasítást hosszú ideig rosszul értelmezve ez a kódjel lényegesen kevesebb T-lapra került rá, mint azt a helyes értelmezés lehetővé és szükségessé tette.

- Emiatt a helyes értelmezés már önmagában is bizonyos fokú emelkedést okozott, és az átmeneti években nehezen lehetett megkülönböztetni a pusztán statisztikai növekedést a ténylegestől.

- A cigány elkövetök összes elkövető közötti arányának alakulását a cigány és nem cigány lakosság demográfiai helyzetének jelentős különbségei is komoly mértékben befolyásolták. ${ }^{33}$

A cigány lakosság helyzetével foglalkozó, a Budapest Főváros Tanácsa mellett müködő Koordinációs Bizottság 1989. október 30-ra ülést hívott össze, amelynek első napirendi pontját, A BRFK tájékoztatója a fövárosi cigánylakosság helyzetét érintö tevékenységéröl ${ }^{34}$ címmel Konczer István rendör vezérőrnagy fökapitány tartotta.

„A föváros bünügyi helyzetét az öt év távlatában értve, az ismertté vált büncselekmények száma az 1984 évi 45.844-röl 88-ban 50.743-ra 10,7\%-kal növekedett. Ebben az ismertté vált elkövetökön belüli cigány elkövetök aránya 84-ben 2,9 százalék 1988-ban 14.6\%." "35

A Fővárosi Tanács Végrehajtó Bizottságának tervgazdasági és munkaügyi föosztálya által összeállított $A$ cigánylakosság foglalkoztatási, szakképzési és

\footnotetext{
30 Németh Zsolt (szerk.): Tauber István emléke és munkássága. ELTE Állam- és Jogtudományi KarMagyar Kriminológiai Társaság-Rendőrtiszti Főiskola, Budapest, 2009, 10. o.

31 Dobos János (1988): i. m. 6-14. o.

32 Dobos János: Mégegyszer a cigánybünözésröl. Belügyi Szemle, 1979/9., 65. o.

33 Dobos János (1988): i. m. 11. o.

34 Budapest Főváros Tanácsa mellett müködő - a cigány lakosság helyzetével foglalkozó - Koordinációs Bizottság ülése, 1989. október 30. Budapest Főváros Levéltára, VI. 12.a. 163 d.

35 A BRFK tájékoztatójához készített háttéranyag. Budapest Főváros Levéltára, VI. 12.a. 163 d.
} 
átképzési problémái címü anyagból egyebek mellett kiderül, hogy a munkáltatók, illetve a munkaerö-közvetítők semmiféle megkülönböztetést nem alkalmaznak a cigány munkavállalókkal szemben, így nem rendelkeznek ilyen jellegü nyilvántartással sem, „....miután nem definiált a »cigány« szó, fogalma sem egyértelmüen"36.

Az említett dobozban található a 2000 irodalmi és társadalmi havilap 1989. augusztusi számából Révész Sándor Nyilt levél Dr. Túrós András vezérörnagyhoz, országos rendőrfőkapitányhoz címü, a rendőrség cigánybünözési adatgyüjtését pikírt stílusban bíráló anyaga. „A cigányvonal országos hálózatának kiépitése, a cigányság iránt megnyilvánuló megkülönböztetett rendöri érdeklödés, a cigány-bünmegelözési tanácsok intézménye indokolatlan előnyhöz juttatja a cigányságot. [...] arra kérném vezérőrnagy urat, hogy a zsidóbünözési statisztikák esetleges bevezetésével egy idöben intézkedjék a zsidóvonal kiépitéséröl és zsidó bünmegelözési tanok felállitásáról..."

Alighanem az említett koordinációs bizottsági ülés egyik hatásaként született az 1990. január 10-én megtartott bünügyi főkapitány-helyettesi értekezleten ismertetett döntés, hogy ezentúl „Az írott és elektronikus sajtóban történö szereplésnél a »cigánybünözés " megfogalmazást használni nem lehet" ${ }^{{ }_{37}}$.

Mint látható, a rendszerváltás időszakához közeledve a Belügyi Szemle cikkeiben is mind gyakrabban felvetödött az az álláspont, szabad-e különbséget tenni cigány- és nem cigány bünözés között, szabad-e egyáltalán cigányproblémáról beszélni. Szabad-e egy réteget vagy akár a bünözőit jellegzetességei, faji hovatartozása alapján külön kategóriaként kezelni?

\section{A kivezető utak}

Pedig a Belügyi Szemle cikkei között több hasznosítható javaslat is született a cigányok bünözéstől való visszatartására.

A helyzetük javítására és a bünözésben való részvételük csökkentése érdekében 1977-ben például célszerünek látszottak a következő javaslatok:

1. A cigány telepek megszüntetésével a lakáshelyzet megoldásában a tanácsi költségvetés mellett a kedvezőbb hitelpolitikai szempontok, a munkahelyi igazgatás szerepét is szorgalmazni kell.

2. Telepítésük magas fokon szervezett munkát, nagy körültekintést igényel.

37 Dr. Balatoni István r. ezredes: Feladatok/ 2/1990 sz. Emlékeztető, VI. 12. a. 4.37d. 
3. Adaptálódásuk elsődleges kérdése a rendszeres munkavégzés, ami hozzásegíti őket az integrálódás anyagi feltételeinek biztosításához.

4. Megfelelö óvodai elhelyezéssel ellensúlyozni kell körülményeik tárgy- és nyelvszegénységét. Általános iskolai jobb előmenetelük érdekében szorgalmazni kell iskolai előkészítésüket. Szükség szerint kisegítő iskolákban kell kulturálódásukról gondoskodni, felül kell vizsgálni az iskolai felmentések és évhalasztások engedélyezését, hogy ezáltal is csökkenjen az iskolázatlanul maradó cigány gyerekek száma.

5. Családi körülményeik többségében még mindig rendezetlenek, sok cigány gyerek apa nélkül nő fel, a családról való gondoskodás nehézségekbe ütközik, s ezt fokozza, hogy a jövedelmüket nem tudják beosztani. Ezek a viszonyok veszélyeztető tényezők a gyermekekre, akiken sokszor segíteni kellene még az állami gondozásba vétellel is.

6. A cigány telepek rendőri ellenőrzése nem megfelelö, egy-egy rendőri akció lebonyolítása sok esetben sematikusan történik.

7. A bünöző cigányok rendőrhatósági felügyelet alá helyezését még szélesebb körűen kell alkalmazni, s mozgásuk korlátozására a lakhelyelhagyási tilalmat is igénybe kell venni. ${ }^{38}$

A cigányság helyzetével kapcsolatos társadalmi probléma megoldását nem lehetett egyedül a rendőrségre hárítani. Amint ez a koordinációs bizottsági ülésre, a budapesti rendőrfőkapitány részére készített háttéranyagból kiderül, a szervezetnek a „cigánybünözés” felszámolására tett több évtizedes erőfeszítéseit sem övezte egyértelmű társadalmi elfogadottság.

„Az alábbi kérdéskörök részletes elemzése várható:

- A cigány lakosság létszámának alakulása a fövárosban és a kerületekben (pl.: III., VII., VIII, IX., XIII., XX.).

- A cigány lakosság bünözésének oka fokozottan hátrányos helyzete; »cigánybünözés « nem létezik.

- A rendörség fellépéseinek bírálata a »cigánybünözéssel« szemben.

- A különbözö kerületi cigány családokkal foglalkozó szociális gondozók szerint a rendörség tölük gyüjt adatokat válogatás nélkül, a nem bünözö cigány családokra is.

- A rendörség az igazoltatások, utcai intézkedések során diszkriminativ módon jár el a cigánysággal szemkel szemben.

- $A$ »börfejüekröl« nem ad a rendörség tájékoztatást.

38 Balázs László: A Pest megyei cigánybűnözésről. Belügyi Szemle, 1977/1., 91-92. o. 
- Ugyanígy a cigányságot sértö magatartásokról, cselekményekröl, az ezekkel kapcsolatos eljárásokról sem tájékoztatnak.

- Moldova könyvben megjelent cigányságot érintő »rendöri« nyilatkozatok.

- Az Egységes ügyészségi-rendörségi statisztika alapján kérdések várhatók a »cigánybünözés«-röl.

- A rendörségen miért van külön csoport a »cigánybünözésre«? Ez sérti a kisebbséget és »sugallja«, hogy a cigányok bünözök, megbélyegzik az etnikumot vagy »nemzeti kisebbséget«.

- A cigányság bünözésen belüli szerepe lényegesen kisebb, mint ahogy az a közvélemény tudatában megjelenik, ennek egyik okozója a rendörség. " ${ }^{39}$

Valóban, az évtizedek során a társadalomban a rendőrség által is táplált „cigánybünözés"-sel kapcsolatos sztereotípia a rendszerváltás előtt már-már önjáróvá vált. Például egy publikáción ${ }^{40}$ bevezetőjében ezt olvashatjuk: „, $A X I X$. század végén Francis Galton a világon elöször végzett összehasonlitást a különbözö etnikumokhoz tartozó személyek ujjbegyi mintái között. Az ö összehasonlitó munkája nyomán kezdödött meg a dermatoglyphiai tulajdonságok tanulmányozása különbözö populációkban. "”il Az cikk konklúziója: „,Amenynyiben a magyar és a cigány lakosság dermatoglyphiai tulajdonságaiban, illetve azok egyes konkrét sajátosságaiban szignifikáns eltérések mutathatók ki, ezek a kriminalisztikai gyakorlatban is felhasználhatóvá válnak. Az eddig megvizsgált minták mennyisége jelenleg még nem teszi lehetövé, hogy adott esetekben egyértelmüségre juthassunk. igy további anyaggyüjtés és számitógépes technikán alapuló matematikai analizis szükséges. "^2

Bárki eldöntheti, ez az út aligha járható...

Mert ,rendfenntartási szintre vinni (süllyeszteni) a roma problematikát több mint bün, hiba, hogy Talleyrand mestert idézzük"*3.

Noha Vavró István a Szemle Fórum rovatában 1984-ben A „,cigánybünözés" vizsgálatának elméleti és módszertani kérdéseiröl írott tanulmányát a következő bevezetővel indította: ,, Sokszor és sok szó esett már e folyóirat hasábjain is a cigánybünözésröl. De van-e értelme egy olyan jelenség elemzé-

39 A BRFK tájékoztatójához készített háttéranyag. Budapest Főváros Levéltára, VI. 12.a. 163 d.

40 Tauszik Nagyezsda - Tóth György: A hazai cigányság és a nem cigány lakosság dermatoglyphiai (ujjnyom) tulajdonságai közötti különbség. Belügyi Szemle, 1987/6.

41 Uo. 111. o.

42 Uo. 115. o.

43 Bíró András: Terminus technicus vagy fajelmélet? Tauber István emléke és munkássága. ELTE Államés Jogtudományi Kar-Magyar Kriminológiai Társaság-Rendőrtiszti Főiskola, Budapest, 2009, 38. o. 
sének, amely bizonytalan elkülönitési ismérveken nyugszik, és eddig még az önálló létezését sem sikerült bizonyitani."

A „cigánybünözés”-sel kapcsolatos „,igányutak” részletes bemutatása után Vavró tanulmányának végkövetkeztetései rávilágítanak a probléma kezelése során egészen a rendszerváltásig, de jó ideig még az után sem kellően értékelt tényezőkre.

„A cigánybünözés kérdésével kapcsolatos álláspontomat összefoglalva tehát annak lényegét a következökben jelölöm meg:

1. Az állampolgári jogegyenlöség és a jogérvényesités lehetösége szempontjából homogén társadalomban az etnikailag különbözö csoportok lehetöségei azonosak. Negativ társadalmi jelenséget ezért etnikai különbséggel magyarázni nem lehet. Az eltérések oka a kulturális színvonal különbözösége.

2. A cigánynak tekintett népesség tudományos igényü vagy akár statisztikailag elfogadható pontosságú meghatározása mind ez ideig nem történt meg. Ennek megfelelöen nem állnak rendelkezésre adatok létszámukról, népességstruktúrájukról, demográfiai és társadalmi jellemzőikröl. Ilyen adatok hiányában pedig a kriminalitási gyakoriságuk különbözöségére vonatkozó álláspontok egzakt módon nem bizonyithatók.

3. A kriminológiai kutatásokból ismeretesek azok az adatok, amelyek társadalmi-gazdasági jellemzök, s így ezek között a bünözés alakulásában szerepet játszó tényezök hatására vonatkoznak. Ezek között külön is kiemelendö az iskolai végzettség szerepe. Ha a bünözést nem kulturális, hanem etnikai sajátosságnak tekintjük, akkor mindenképpen téves úton járunk, s e tévedés eredményeként elmulaszthatjuk felhivni a figyelmet azoknak a kötelezettségeknek a teljesitésére, amelyek bizonyos társadalmi rétegek kulturális elmaradottságának felszámolása érdekében nélkülözhetetlenek.

4. Az etnikai sajátosságok szerepének hangsúlyozása - különösen, ha egyrészt a sajátosságokat nem fogalmazzuk meg pontosan, másrészt, ha nem is bizonyitjuk, szükségtelen különbségtételt, adott esetben elfogultságot, és ennek eredményeként szembenállást szülhet. Ennek hatásai oly mértékben nemkivánatosak, hogy az már messze túlnö a büntetö jogalkalmazás s igy a kriminológia tárgykörén is. " ${ }_{44}$

44 Vavró István: A „,igánybünözés” vizsgálatának elméleti és módszertani kérdéseiről. Belügyi Szemle, 1984/2., 67-68. o. 


\section{Összegzés}

A Belügyi Szemle tárgyalt témában megjelenő írásait is mindinkább áthatja az az eszmei tartalom, amelyről 2000-ben Geskó Sándor tanulmányt készített ${ }^{45}$. A kötet előszavában Kaltenbach Jenő hangsúlyozta: „, A modern állam legalapvetőbb feladata a társadalmi integráció garantálása, azaz a társadalmi konfliktusok civilizált feloldásában való közremüködés. " 46

Tanulmányában Geskó hangsúlyozza; az elöítéletek diszkrimináció formájában való megjelenésének két alapvető korlátja lehet. Az egyik a törvényi szabályozás, amely - ha a napi gyakorlatban érvényre jut - megtiltja a hátrányos megkülönböztetést. A másik korlát a társadalmi attitüdök, szokásrendszerek megváltoztatása, olyan átalakulása, amely nem támogatja, hanem elítéli a diszkrimináció minden formáját.

Európa multikulturális világában napjainkban is mindinkább felértékelödik az interkulturális párbeszéd jelentősége.

A Belügyi Szemle 2008. májusi számában ${ }^{47}$ megjelenő írás jó adalékul szolgálhat a cigányokat érintő 2008-2009-es gyilkosságsorozat társadalmi háttértényezőinek megértéséhez: az elmúlt másfél évtized kétségkívül jó szándékú intézkedései számottevően nem javítottak a cigányság helyzetén. A társadalom jelentős részében viszont azt tudatosították, hogy több milliárd forintot költenek a cigány népességre, a jelek szerint értelmetlenül. Pedig az ilyen terveknél nem a jó szándékkal van a baj, hanem a tisztázatlan célokkal, elvekkel. A rendszerváltozás óta sem az aktuális kormányzó elit, sem a roma politika képviselői nem tudják eldönteni, hogy van-e „cigányügy”. ${ }^{48}$

\footnotetext{
45 Geskó Sándor: Rendőrök és romák: konfliktusok, vagy párbeszéd. Mediátor Tanácsadó Iroda, Budapest, 2000

46 Uo. 5. o.

47 Kállai Ernő: A kisebbségi ombudsman tevékenysége és a roma közösségek. Belügyi Szemle, 2008/5. 48 Uo. 23. o.
} 